\section{A Long-term Comparison of Broadcast Application versus Drip Fertigation of Nitrogen for Mature Pecan Trees}

\author{
R.E. Worley', J.W. Danie1 ${ }^{2}$, \\ J.D. Dutcher, ${ }^{3}$ K.A. Harrison", \\ and B .G. Mullinix ${ }^{5}$
}

Additional index words. Carya illinoensis, fertilizer

Summary. No reduction in yield and quality of pecan nuts or leaf mineral nutrient concentration occurred when $100 \mathrm{lb} /$ acre of $\mathrm{N}$ was applied through a drip-irrigation system compared with $200 \mathrm{lb} /$ acre applied either all broadcast or half broadcast and half fertigated. Yield of 'Stuart', percentage kernel of 'Schley', and nut size of both cultivars were increased by irrigation or irrigation and fertigation. The $100 \mathrm{lb} / \mathrm{acre} \mathrm{N}$-allfertigated treatment resulted in less soil $\mathrm{pH}$ reduction and less loss of $\mathrm{K}$, $\mathrm{Ca}$, and $\mathrm{Mg}$ from soil underneath the tree canopy than broadcast treatments. No evidence of excessive soil $\mathrm{pH}$ reduction in the wetted zone of fertigated trees was noticed. Calcium and $\mathrm{Mg}$ were higher within than outside the wetted zone.

${ }^{2}$ Dept. of Horticulture, University of Georgia, Tifton, GA 31793-0748.

${ }^{2}$ Professor Emeritus, Dept. of Horticulture, Uiversity of Georgia, Griffin, GA 30223-1797.

${ }^{3}$ Dept. of Entomology, University of Georgia, Tifton, GA 31793-0748.

"Dept. of Biological and Agricultural Engineering, University of Georgia Cooperative Extension Semite, Tifton, GA 31793-1209.

${ }^{5}$ Statistical and Computer Services Unit, University of Georgia, Tifton, GA 31793-0748.

The cost of publishing this paper was defrayed in part by the payment of page charges, Under postal regulations, this paper therefore must be hereby marked advertisement solely to indicate tbis fact.
A ddition of $\mathrm{N}$ fertilizer periodically throughout the growing season in irrigation water provides the best means of fertilization without injury to plants (Stanford and Legg, 1984). Fertigation has proven to be an economical method of applying nutrients to several fruit species (Klein et al., 1989; Smith et al., 1979). Compaction is a serious problem in many pecan [Carya illinoensis (Wangenh) C. Koch] orchards (Trouse, 1978). If feasible and efficient, fertigation could save pecan growers millions of dollars through reduced compaction from the fertilizer application truck, reduced application costs, and more efficient use of applied fertilizer through reduced leaching losses. The elimination of one application of $100 \mathrm{lb} /$ acre of $\mathrm{N}$ on the 150,000 acres of pecans in Georgia alone would amount to a saving of more than $\$ 4$ million just in material costs. Less applied $\mathrm{N}$ also means less pollution of surface and ground water. Trials on young pecan trees indicate that fertigation through the drip system is feasible and more efficient than conventional methods of application (Aitken, 1986). This paper reports results of a 10-year study on feasibility of applying $\mathrm{N}$ to old pecan trees via drip irrigation. A similar study on peaches at Fort Valley, Ga. (Edwards et al., 1982), reported a substantial soil $\mathrm{pH}$ reduction in the wetted zone from fertigated N. Our study also was designed to determine if soil $\mathrm{pH}$ reduction by fertigation was a problem with pecan.

\section{Materials and methods}

Thisstudy was originally a part of a larger entomological study on an old (estimated $>50$-year-old) pecan orchard on President Jimmy Carter's family estate near Plains, Ga. The 35acre orchard consists mainly of 'Stuart' and 'Schley' trees growing on Red Bay and Greenville soil. This location is within 50 miles of Albany, Ga., and within the area and on soil types that produce about one-third of the world's pecans. The orchard had been abandoned, but was brought back into production in the late 1970s. It is typical of many older pecan orchards that produce most of the world's crop. The statistical design was a split-plot with three replications.Main plots consisted of eight insect control treatments, and subplots consisted of four 
irrigation-fertilizer treatments. Each plot of up to five trees contained one or more 'Stuart' and 'Schley' trees. The irrigation-fertilizer treatments were replicated 24 times. This paper concerns only the results of the irrigation-fertilizer subplot treatments. The whole-plot treatments were discontinued in 1982, and results of whole-plot treatments were reported previously (Dutcher et al., 1984). Irrigation-fertilizer treatments were as follows.

1) No irrigation-200 lb/acre (224 $\mathrm{kg} \cdot \mathrm{ha}^{-1}$ ) $\mathrm{N}$ with all the $\mathrm{N}$ surfacebroadcast. One-half of the $\mathrm{N}$ was applied about 1 Apr. and the remainder about 1 June.

2) Drip irrigation with $200 \mathrm{lb} /$ acre $\mathrm{N}$ broadcast as for (1).

3) Drip irrigation with $100 \mathrm{lb} /$ acre (112 kg.ha-1) N broadcast as for (1) plus $25 \mathrm{lb} /$ acre $\left(28 \mathrm{~kg} \cdot \mathrm{ha}^{-1}\right) \mathrm{N}$ injected into the irrigation water (fertigated) about 1 Apr., 1 May, 1 June, and 1 July for a total of 100 $\mathrm{lb} /$ acre $\mathrm{N}$ fertigated.

4) No broadcast N with $100 \mathrm{lb} /$ acre $\mathrm{N}$ fertigated as for (3).

All the broadcast $\mathrm{N}$ was from ammonium nitrate. A line of emitters was placed within the herbicide strip on two sides of each tree and two 2gal/h emitters were spaced about 4 feet apart on each side of each tree on each line for a total of eight emitters per tree. When fertigating, the valves for the irrigation lines for the nonfertigated but irrigated trees were turned off. All irrigated trees received the same amount of irrigation water except for the four times each year when fertigation occurred. The irrigation system was operated $1 \mathrm{~h}$ (or more, usuallyovernight)aftereachfertigation to flush the system and distribute the $\mathrm{N}$ through the wetted zone. Otherwise, irrigation was applied $12 \mathrm{~h} /$ day beginning about 3 days after each rain of 1 inch during the growing season, or if there was visual indication of need. This method approximates recommended irrigation practices for growers in the area.

In 1980, the injected $\mathrm{N}$ source wasprilled calcium nitrate. This material was difficult to inject due to the clay coating of the prills. Thereafter, liquid Uran ( 16\% N from urea, 16\% N from ammonium nitrate) was the $\mathrm{N}$ source. The injection rate was $25 \mathrm{gal}$ of the concentrated solution/h after the first year. Additional nutrients and lime were added uniformly to all trees each spring if leaf or soil analysis indicated need. Calcium hydroxide at $2.3 \mathrm{lb} /$ emitter was applied within 1 foot (30 $\mathrm{cm}$ ) of emitters in fertigated plots on 5 May 1981 to neutralize the anticipatedacidityin the wetted zone caused by the injected $\mathrm{N}$.

Yieldandquality data were taken for each tree and presented separately for 'Stuart' and 'Schley'. A 50-nut sample was taken from each tree at harvest, sized by categories separated by $1 / 16$ inch $(0.16 \mathrm{~cm})$ of diameter, and then cracked. Kernels were graded into fancy, standard, and amber grades and percentage of each size, kernel grade, and total percentage edible kernelwascalculated. Fancy kernels were plump, well-filled kernels of the brightest color. Standard kernels were similar, but darker. Amber kernels were darker than standard kernels and/or had edible kernels with defects.

Leafsamplesweretakenfromeach plot between the second week in July through the first week of August and soil samples were taken in winter each year.The samples were analyzed using atomic absorption procedures for cations, colorometric procedures for $\mathrm{P}$, and Kjeldahl for N ( Worley, 1974;

Table 1. Yield and quality of 'Schley'pecans when not irrigated, drip-irrigated (DI), and fertigated (F) with $N$.

\begin{tabular}{|c|c|c|c|c|c|c|c|c|c|c|c|c|c|}
\hline \multicolumn{2}{|c|}{$\mathbf{N}$ applied } & \multirow[b]{2}{*}{ DI } & \multirow[b]{2}{*}{1980} & \multirow[b]{2}{*}{1981} & \multirow[b]{2}{*}{1982} & \multirow[b]{2}{*}{1983} & \multirow[b]{2}{*}{1984} & \multirow[b]{2}{*}{1985} & \multirow[b]{2}{*}{1986} & \multirow[b]{2}{*}{1987} & \multirow[b]{2}{*}{1988} & \multirow[b]{2}{*}{1989} & \multirow[b]{2}{*}{ Mean } \\
\hline $\begin{array}{l}\text { Broadcast } \\
\text { (lb/acre) }\end{array}$ & $\underline{F}$ & & & & & & & & & & & & \\
\hline \multicolumn{14}{|c|}{ Yield $(\text { lb/tree })^{z}$} \\
\hline 200 & 0 & No & $64 a^{y}$ & $32 b$ & $18 \mathrm{a}$ & $2 a$ & $46 a$ & $29 a$ & $20 a$ & $44 \mathrm{a}$ & $41 b$ & $28 \mathrm{a}$ & $32 a$ \\
\hline 200 & 0 & Yes & $65 \mathrm{ab}$ & $26 \mathrm{ab}$ & $12 \mathrm{a}$ & $2 \mathrm{a}$ & 38 a & $21 \mathrm{a}$ & $27 \mathrm{a}$ & $78 \mathrm{~b}$ & $29 a b$ & $25 \mathrm{a}$ & $33 a$ \\
\hline 100 & 100 & Yes & $78 \mathrm{c}$ & $22 \mathrm{ab}$ & $20 a$ & $7 \mathrm{a}$ & $40 \mathrm{a}$ & $26 \mathrm{a}$ & $28 \mathrm{a}$ & $76 \mathrm{~b}$ & $32 \mathrm{ab}$ & $24 \mathrm{a}$ & $36 a$ \\
\hline 0 & 100 & Yes & $75 \mathrm{bc}$ & $19 a$ & $14 \mathrm{a}$ & $2 \mathrm{a}$ & $37 \mathrm{a}$ & $24 \mathrm{a}$ & $23 \mathrm{a}$ & $73 \mathrm{~b}$ & $25 \mathrm{a}$ & $28 \mathrm{a}$ & $32 \mathrm{a}$ \\
\hline $\mathrm{N}$ & & & 40 & 38 & 40 & 40 & 39 & 32 & 40 & 40 & 27 & 40 & 376 \\
\hline $\operatorname{LSD}(0.05)$ & & & 10.0 & 10.3 & 10.0 & 10.0 & 10.2 & 11.2 & 10.0 & 10.0 & 12.2 & 10.0 & 6.0 \\
\hline \multicolumn{14}{|c|}{ Percent kernel } \\
\hline 200 & & No & $57 \mathrm{a}$ & $51 \mathrm{a}$ & $56 a$ & 51 a & $50 \mathrm{a}$ & $53 a$ & $56 \mathrm{a}$ & $50 a$ & $56 \mathrm{~b}$ & $52 \mathrm{a}$ & $53 \mathrm{a}$ \\
\hline 200 & 0 & Yes & $58 \mathrm{a}$ & $5 \mathrm{I} \mathrm{a}$ & $54 \mathrm{a}$ & $50 \mathrm{a}$ & $53 \mathrm{~b}$ & $53 a$ & $55 \mathrm{a}$ & $58 c$ & 53 a & $53 a$ & 54 a \\
\hline 100 & 100 & Yes & $58 \mathrm{a}$ & $52 \mathrm{a}$ & 55 a & $50 \mathrm{a}$ & $52 \mathrm{ab}$ & $54 \mathrm{a}$ & $55 \mathrm{a}$ & $56 \mathrm{~b}$ & $55 \mathrm{ab}$ & 52 a & 54 a \\
\hline 0 & 100 & Yes & $58 \mathrm{a}$ & $52 \mathrm{a}$ & $55 \mathrm{a}$ & 53 a & $52 \mathrm{ab}$ & $54 \mathrm{a}$ & $55 \mathrm{a}$ & $55 \mathrm{~b}$ & $55 \mathrm{ab}$ & $54 \mathrm{a}$ & 54 a \\
\hline $\mathrm{N}$ & & & 36 & 24 & 35 & 3 & 37 & 26 & 29 & 38 & 24 & 36 & 288 \\
\hline $\operatorname{LSD}(0.05)$ & & & 2.1 & 2.6 & 2.2 & 7.3 & 2.1 & 2.5 & 2.4 & 2.1 & 2.6 & 2.1 & 1.2 \\
\hline \multicolumn{14}{|c|}{$N u t s / l b^{y}$} \\
\hline 200 & 0 & No & $107 \mathrm{~b}$ & $93 \mathrm{~b}$ & $76 \mathrm{a}$ & $68 \mathrm{a}$ & $85 \mathrm{~b}$ & $76 \mathrm{~b}$ & $93 c$ & $82 \mathrm{~b}$ & $72 \mathrm{~b}$ & $84 \mathrm{a}$ & $86 \mathrm{~b}$ \\
\hline 200 & 0 & Yes & $70 \mathrm{a}$ & $69 \mathrm{a}$ & $72 \mathrm{a}$ & $60 \mathrm{a}$ & $78 \mathrm{a}$ & $71 \mathbf{a}$ & $80 \mathrm{a}$ & $73 a$ & $66 \mathrm{a}$ & 82 a & $74 \mathrm{a}$ \\
\hline 100 & 100 & Yes & $74 \mathrm{a}$ & $73 a$ & $73 \mathbf{a}$ & $69 \mathrm{a}$ & $82 \mathrm{ab}$ & $71 \mathrm{a}$ & $86 \mathrm{~b}$ & $73 a$ & $69 \mathrm{ab}$ & 81 a & $76 a$ \\
\hline 0 & 100 & Yes & $70 a$ & $72 \mathrm{a}$ & $72 \mathrm{a}$ & $62 \mathrm{a}$ & $78 \mathrm{a}$ & $73 \mathrm{ab}$ & $77 \mathrm{a}$ & $73 \mathrm{a}$ & $67 \mathrm{ab}$ & $83 a$ & $74 \mathrm{a}$ \\
\hline $\mathrm{N}$ & & & 39 & 72 & 36 & 3 & 38 & 32 & 29 & 39 & 24 & 36 & 306 \\
\hline $\operatorname{LSD}(0.05)$ & & & 4.0 & 4.5 & 4.1 & 14.3 & 4.0 & 4.4 & 4.6 & 4.0 & 5.1 & 4.1 & 5.2 \\
\hline
\end{tabular}

Fertilizer $\times$ year interaction significant at 50.05.

${ }^{\prime M}$ Mean separation for variable within columns by Duncan's NMRT $(P=0.05)$. 
Worley et al., 1974). Additional soil samples were taken within 1 to 2 feet of each emitter to determine the effect of fertigation on soil in the wetted zone.

Thestatisticaldesignusedforanalysis of the data was a split-plot in time where replications (replications + whole plot insecticide treatments) and irrigation-fertilizer treatments were the main plots, multiple trees receiving the same treatment in the same replication were the sampling error, and yearly measurements were the subplots (Steel and Torrie, 1960). Because time was not randomized, replication by time was used as the source of error for years. To test irrigation-fertilizer treatment main effects, the greater of either replication by treatment or treatment by year was used as the source of error (Steel and Torrie, 1960). Due to missing plots because trees died or did not produce yield, least-square means were not available.

\section{Results and discussion}

Some of the insect control treatments reduced yield; thus, irrigationfertilizer treatment yields were lower thanif they had received the best insect control during the first 3 years of the
study.Yield varied greatly from year to yeardueto the irregular bearing nature of pecans (Wood et al., 1991). Yield from the fertigated plots receiving the low $\mathrm{N}$ rate was as good as those receiving twice the $\mathrm{N}$ rate, either broadcast or part injected through the drip system (Tables 1 and 2). Increases in yield from irrigation or irrigation plus fertigation were apparent in 1980 and 1987 for 'Schley' and in 1980, 1981, 1984, 1986, and 1987 for 'Stuart' and for the 10year average for 'Stuart'. 'Stuart' yields were almost doubled by irrigation alone or by fertigation in 1980 and 1987, but were not affected by treatments in 4 of the 10 years. Irregular bearing is probablyresponsibleforthesmallincreasein yieldfor the nonirrigated plots over the other treatments for 'Schley' in 1981 and 'Stuart' in 1982. The relatively high yield for nonirrigated 'Stuart' trees in 1982 followed 2 years of relatively low yield. Also, the relatively high yield of nonirrigated 'Schley' in 1981 followed a relatively low yield in 1980. Note also that there is not a clear-cut on-off year sequence.

Kernel quality was not affected consistently by treatments over the years (nut diameter and kernel grade data not shown in tables). Both kernel quality and nut size were as good or better for the low-N-all-fertigated treatment as for the other treatments (Tables 1 and 2). 'Schley' percentagekernel was reduced by three percentage points in 1984 and eight percentage points in 1987 when irrigation was withheld (Table 1); however, percentage kernel for 'Stuart' was not affected by treatments in any year except 1984, when withholding water reduced percentage kernel below the half-fertigated treatment (Table 2). Withholding irrigation increased percentage fancy and reduced percentage standard kernels of 'Schley in 1980, but not in other years (data not shown ). The most consistent quality difference was in nut size as shown by nuts/lb count and volume/nut (Tables 1 and 2). Nonir-rigated trees usually produced smaller nuts (>nuts/lb count) than the irrigated trees.

Other experiments have indicated that a leaf $\mathrm{N}$ concentration of $2.75 \%$ or greater is sufficient for optimum tree growth, nut yield, and nut quality (Worley, 1985, 1990). Leaf concentrations were $2.56 \%$ in all years and $>2.75 \%$ for all treatments in 6 of 9 years (Table 3). Leaf $\mathrm{N}$ was above $3.00 \%$ for all treatments in 1988. Differences in leaf $\mathrm{N}$, though sometimes

Table 2.. Yield and quality of 'Stuart' pecans when not irrigated, drip irrigated (DI), and fertigated(F).

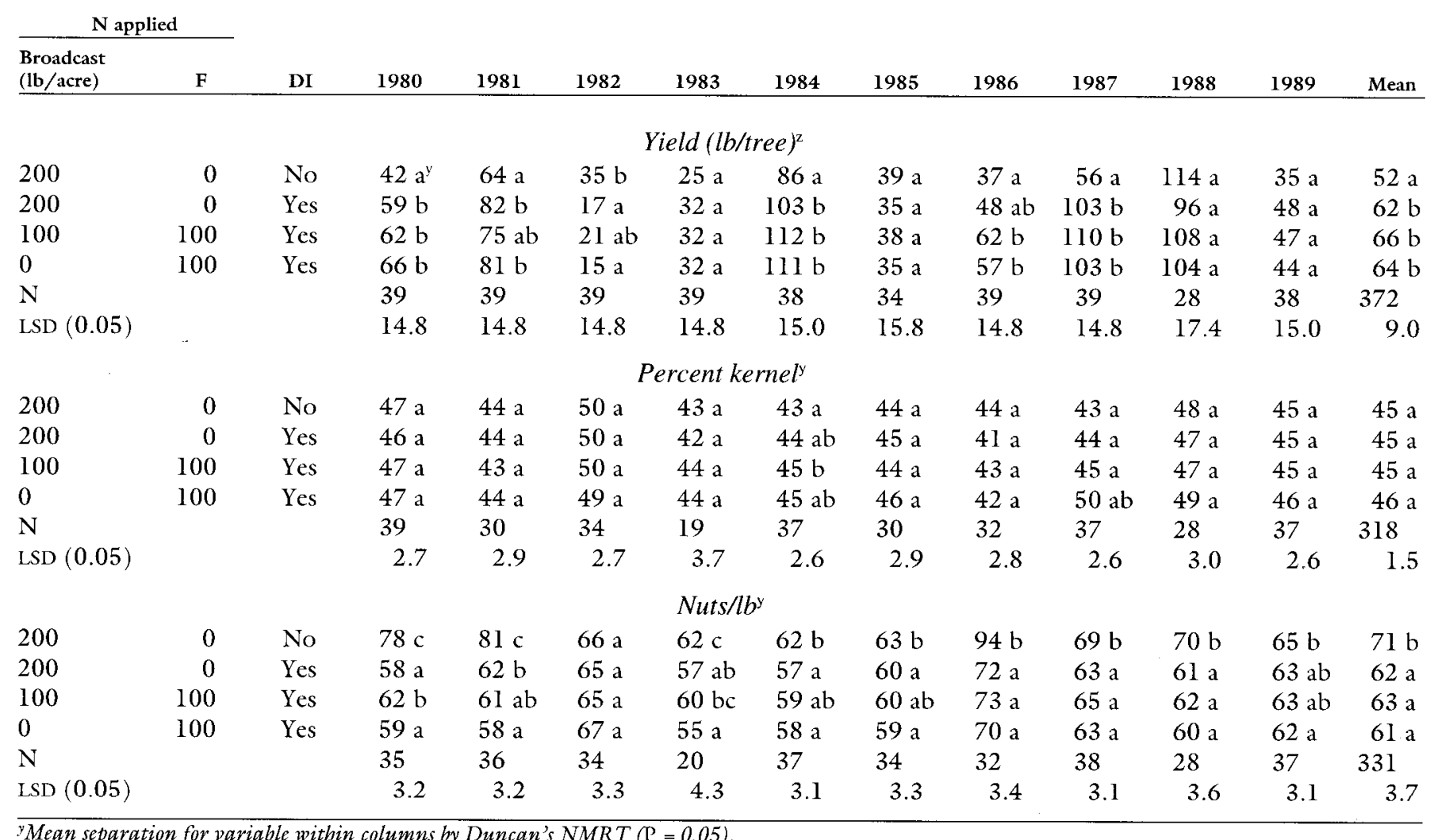

${ }^{z}$ Fertilizer $\times$ year interaction: yield $(\mathrm{P}<0.01)$, percent kernel $(\mathrm{P}>0.10)$, nuts $/ l b(\mathrm{P}<0.01)$. 


\section{$\mathrm{N}$ applied}

\begin{tabular}{|c|c|c|c|c|c|c|c|c|c|c|c|c|}
\hline $\begin{array}{l}\text { Broadcast } \\
\text { (lb/acre) }\end{array}$ & $\mathbf{F}$ & DI & 1981 & 1982 & 1983 & 1984 & 1985 & 1986 & 1987 & 1988 & 1989 & Mean \\
\hline 200 & 0 & No & $2.85 \mathrm{a}^{2}$ & $2.68 \mathrm{a}$ & $3.09 \mathrm{a}$ & $2.91 \mathrm{a}$ & $2.62 \mathrm{a}$ & $2.67 \mathrm{a}$ & $2.89 \mathrm{a}$ & $3.11 \mathrm{a}$ & $2.99 \mathrm{a}$ & $2.87 \mathrm{a}$ \\
\hline 200 & 0 & Yes & $2.89 \mathrm{a}$ & $2.67 \mathrm{a}$ & $3.10 \mathrm{a}$ & $2.93 \mathrm{a}$ & $2.61 \mathrm{a}$ & $2.71 \mathrm{a}$ & $2.86 \mathrm{ab}$ & $3.12 \mathrm{a}$ & $2.93 \mathrm{ab}$ & $2.87 \mathrm{a}$ \\
\hline 100 & 100 & Yes & $2.91 \mathrm{a}$ & $2.69 \mathrm{a}$ & $3.01 \mathrm{~b}$ & $2.91 \mathrm{a}$ & $2.68 \mathrm{a}$ & $2.69 \mathrm{a}$ & $2.81 \mathrm{~b}$ & $3.10 \mathrm{a}$ & $2.88 \mathrm{~b}$ & $2.85 \mathrm{a}$ \\
\hline 0 & 100 & Yes & $2.89 \mathrm{a}$ & $2.56 \mathrm{~b}$ & $3.00 \mathrm{~b}$ & $2.90 \mathrm{a}$ & $2.63 \mathrm{a}$ & $2.68 \mathrm{a}$ & $2.85 \mathrm{ab}$ & $3.09 \mathrm{a}$ & $2.90 \mathrm{~b}$ & $2.83 \mathrm{a}$ \\
\hline
\end{tabular}

$\operatorname{LSD}(0.05)=0.067,23<\mathrm{N}<24$ (yearly); LSD $(0.05)=0.041, \mathrm{~N}=214$ (overall)

${ }^{z}$ Mean separation for vaiable within columns by Duncan's $N M R T(\mathrm{P}=0.05)$.

Table 4. Leaf mineral concentrations with $N$ applications by broadcast or fertigation (means of 9 years).

\begin{tabular}{|c|c|c|c|c|c|c|c|c|c|}
\hline B roadcast & Fertigation & $\begin{array}{c}P \\
\text { (lb/acre) }\end{array}$ & $\begin{array}{c}\mathrm{K} \\
(\mathrm{lb} / \mathrm{acrc}) \\
\end{array}$ & $\begin{array}{c}\mathrm{Ca} \\
\text { (lb/acre) }\end{array}$ & $\begin{array}{c}\mathrm{Mg} \\
\text { (lb/acre) }\end{array}$ & $\begin{array}{c}F e \\
\left(\mu \mathrm{g} \cdot \mathrm{g}^{-1}\right)\end{array}$ & $\begin{array}{c}\mathrm{Zn} \\
\left(\mu \mathrm{g} \cdot \mathrm{g}^{-1}\right)\end{array}$ & $\begin{array}{c}\mathrm{Mn} \\
\left(\mu \mathrm{g} \cdot \mathrm{g}^{-1}\right)\end{array}$ & $\begin{array}{c}\mathrm{Cu} \\
\left(\mu \mathrm{g} \cdot \mathrm{g}^{-1}\right)\end{array}$ \\
\hline 200 & 0 & $0.127 \mathrm{a}$ & $0.84 \mathrm{~b}$ & $1.46 \mathrm{a}$ & $0.39 \mathrm{a}$ & $62 \mathrm{~b}$ & $89 a$ & $268 \mathrm{ab}$ & $9.3 \mathrm{a}$ \\
\hline 200 & 0 & $0.128 \mathrm{a}$ & $0.80 \mathrm{ab}$ & $1.47 \mathrm{a}$ & $0.41 \mathrm{~b}$ & $60 \mathrm{ab}$ & 99 a & $270 \mathrm{ab}$ & $10.0 \mathrm{c}$ \\
\hline 100 & 100 & $0.128 \mathrm{a}$ & $0.82 \mathrm{ab}$ & $1.47 \mathrm{a}$ & $0.39 \mathrm{a}$ & 59 a & $97 \mathrm{a}$ & $276 \mathrm{~b}$ & $9.6 \mathrm{~b}$ \\
\hline 0 & 100 & $0.131 \mathrm{~b}$ & $0.79 \mathrm{a}$ & $1.48 \mathrm{a}$ & $0.41 \mathrm{~b}$ & $59 a$ & $96 \mathrm{a}$ & $263 a$ & $10.0 \mathrm{c}$ \\
\hline \multicolumn{10}{|l|}{ Interaction } \\
\hline Fertilizer $\times$ year & & NS & ** & NS & * & $\star$ & NS & * & $\star \star$ \\
\hline $\operatorname{LSD}(0.05), \mathrm{N}=214$ & & 0.0024 & 0.041 & 0.060 & 0.019 & 2.73 & 11.0 & 11.8 & 0.34 \\
\hline
\end{tabular}

"Means separated within columns by Duncan's NMRT.

${ }_{N s,}^{*},{ }^{* *}$ Nonsignificant or significant at $\mathrm{P} \leq 0.05$ or 0.01 , respectively.

Table 5. Soil analysis for random samples taken underneath trees outside of wetted zone (mean of 6 years).

\begin{tabular}{|c|c|c|c|c|c|c|c|c|c|c|c|c|}
\hline & & \multicolumn{7}{|c|}{$0-6$ inches } & \multicolumn{4}{|c|}{$6-12$ inches } \\
\hline \multicolumn{2}{|c|}{$\mathbf{N}$ applied } & \multirow[b]{2}{*}{$\begin{array}{c}\text { Drip } \\
\text { irrigation }\end{array}$} & \multirow[b]{2}{*}{$\begin{array}{l}\text { Soil } \\
\mathrm{pH}\end{array}$} & \multirow{2}{*}{$\begin{array}{c}\text { Soil } \\
\mathbf{P} \\
\text { (lb } / \text { acre) }\end{array}$} & \multirow{2}{*}{$\begin{array}{c}\text { Soil } \\
\mathrm{K} \\
\text { (lb/acre) }\end{array}$} & \multirow{2}{*}{$\begin{array}{c}\text { Soil } \\
\text { Ca } \\
\text { (lb/acre) }\end{array}$} & \multirow{2}{*}{$\begin{array}{c}\text { Soil } \\
\mathrm{Mg} \\
\text { (lb/acre) }\end{array}$} & \multirow[b]{2}{*}{$\begin{array}{r}\text { Soil } \\
\text { pH }\end{array}$} & \multirow{2}{*}{$\begin{array}{c}\text { Soil } \\
\text { P } \\
\text { (lb/acre) }\end{array}$} & \multirow{2}{*}{$\begin{array}{c}\text { Soil } \\
\mathrm{K} \\
\text { (lb/acre) }\end{array}$} & \multirow{2}{*}{$\begin{array}{c}\text { Soil } \\
\text { Ca } \\
\text { (lb/acre) }\end{array}$} & \multirow{2}{*}{$\begin{array}{c}\text { Soil } \\
\mathrm{Mg} \\
\text { (lb/acre) }\end{array}$} \\
\hline $\begin{array}{l}\text { Broadcast } \\
\text { (lb/acre) }\end{array}$ & $\begin{array}{c}\text { Fertigation } \\
\text { (lb/acre) }\end{array}$ & & & & & & & & & & & \\
\hline 200 & 0 & No & $5.0 \mathrm{a}^{z}$ & $89 a$ & $152 \mathrm{a}$ & $1163 \mathrm{a}$ & $254 \mathrm{a}$ & $4.7 \mathrm{a}$ & $32 \mathrm{a}$ & $92 \mathrm{a}$ & $415 a$ & $91 \mathrm{a}$ \\
\hline 200 & 0 & Yes & $4.9 \mathrm{a}$ & 79 a & $163 \mathrm{ab}$ & $1128 \mathrm{a}$ & $263 a$ & $4.7 \mathrm{a}$ & $29 a$ & $104 \mathrm{ab}$ & $464 \mathrm{ab}$ & $109 a$ \\
\hline 100 & 100 & Yes & $5.1 \mathrm{a}$ & $84 \mathrm{a}$ & $174 b$ & $1250 \mathrm{a}$ & $267 \mathrm{a}$ & $4.8 \mathrm{~b}$ & $33 a$ & $110 \mathrm{~b}$ & $544 \mathrm{~b}$ & $114 \mathrm{a}$ \\
\hline 0 & 100 & Yes & $5.4 \mathrm{~b}$ & $86 a$ & $201 \mathrm{c}$ & $1524 \mathrm{~b}$ & $335 \mathrm{~b}$ & $5.0 \mathrm{c}$ & $28 \mathrm{a}$ & $125 c$ & $678 c$ & $151 \mathrm{~b}$ \\
\hline LSD $(0.05$ & $\mathrm{J}=143$ & & 0.17 & 9.6 & 19.4 & 234 & 41.0 & 0.11 & 5.9 & 14.7 & 98.7 & 25.3 \\
\hline \multicolumn{13}{|c|}{ Interaction } \\
\hline Fertilize & year & & * * & * & NS & NS & NS & $\star \star *$ & NS & * * & NS & * * \\
\hline
\end{tabular}

${ }^{2}$ Mean separation within columns by Duncan's NMRT.

${ }_{N S,}^{*},{ }^{* *}$ Nonsignificant at $\mathrm{P} \leq 0.05$ or 0.01 , respectively.

significant statistically, were small and of no practical significance. All treatments supplied adequate $\mathrm{N}$.

The mean leaf concentrations for other nutrients over the 10 -year period were not different $(P=0.05)$ for $\mathrm{Ca}$ and $\mathrm{Zn}$. Leaf $\mathrm{P}, \mathrm{Mg}, \mathrm{Mn}$, and $\mathrm{Cu}$ were slightly higher for some irrigated trees than for those not irrigated, but the differences were too small for practical significance (Table 4). Leaf Fe was highest for nonirrigated trees. No visual nutrient deficiency symptoms were obvious in the orchard. Except for the possible low $\mathrm{K}$ levels in some years (data not shown), leaf nutrient levelswere considered adequate for all treatments.

Soil $\mathrm{pH}$ for the randomly selected soil samples from outside the wetted zone reflected the acid-forming effect of broadcast N. Soil pH, K, Ca, and
$\mathrm{Mg}$ was usually greatest in the plots receiving the low-N-all-fertigated treatment, because no $\mathrm{N}$ was applied in the areasampled (Table 5). Apparently, the $\mathrm{H}$ ions formed during the vitrification process of the ammonium nitrate lowered the $\mathrm{pH}$ and replaced the basic cations on the exchange complex, thus releasing them to the soil solution for leaching. Soil $\mathrm{pH}$ was greater in 4 years when half the $\mathrm{N}$ was applied through a drip system than when all was broadcast under nonirrigated trees (data not shown).Soil P was affected very little by the treatments.

A lowering of $\mathrm{pH}$ around the emitters when $\mathrm{N}$ was fertigated was not observed in this study (Table 6 ) or that of Aitkin (1986), in contrast to the report of Edwards et al. (1986) for peaches. The calcium hydroxide applied around emitters in 1981 (treat- ments 3 and 4) might have helped to prevent excessive $\mathrm{pH}$ reduction in the wetted zone. Irrigation without the calcium hydroxide (treatment 2 ) increased the $\mathrm{pH}$ in the wetted zone compared with the nonirrigated control. This suggests that basic minerals in the irrigation water might be preventing a lower $\mathrm{pH}$ in the wetted zone. An analysis of the irrigation water in 1993 revealed $0.95 \mu \mathrm{g} \cdot \mathrm{g}^{-1} \mathrm{Ca}$, $1.81 \mu \mathrm{g} \cdot \mathrm{g}^{-1} \mathrm{Mg}$, and $4.11 \mu \mathrm{g} \cdot \mathrm{g}^{-1} \mathrm{Na}$, which would have reduced much of the acidity created by the N. Irrigation caused an unexplained loss of soil test $\mathrm{P}$ in the wetted zone. Irrigation + fertigation also increased soil test $\mathrm{Ca}$ and $\mathrm{Mg}$ concentrations in the wetted zone compared with soil tests from the broadcast nonirrigated plots. Much of this increase could have come from the calcium hydroxide and the irrigation 


\begin{tabular}{|c|c|c|c|c|c|c|c|}
\hline \multirow[b]{2}{*}{$\begin{array}{l}\text { Broadcast } \\
\text { (lb/acre) }\end{array}$} & \multirow[b]{2}{*}{$\begin{array}{c}\text { Fertigated } \\
\text { (lb/acre) }\end{array}$} & \multirow[b]{2}{*}{$\underset{\text { Dripigated }}{\text { irrigated }}$} & \multirow[b]{2}{*}{$\mathrm{PH}$} & \multicolumn{4}{|c|}{ Soil analysis (emitter; 7-year mean) } \\
\hline & & & & $\begin{array}{c}\mathrm{P} \\
\text { (lb/acre) }\end{array}$ & $\begin{array}{c}\mathrm{K} \\
\text { (lb/acre) }\end{array}$ & (lb/acre) & (lb/acre) \\
\hline 200 & 0 & $\mathrm{No}^{\mathrm{y}}$ & $4.99 \mathrm{a}$ & $85 \mathrm{~b}$ & 126 a & 951 a & 222 a \\
\hline 200 & 0 & Yes & $5.25 \mathrm{~b}$ & $68 \mathrm{a}$ & $134 \mathrm{a}$ & $1086 \mathrm{ab}$ & $283 \mathrm{~b}$ \\
\hline 100 & 100 & Yes & $5.28 \mathrm{~b}$ & $68 \mathrm{a}$ & 127 a & $1282 \mathrm{bc}$ & $270 \mathrm{~b}$ \\
\hline o & 100 & Yes & $5.41 \mathrm{~b}$ & $63 \mathrm{a}$ & $130 \mathrm{a}$ & $1340 \mathrm{c}$ & $312 b$ \\
\hline \multicolumn{8}{|c|}{ Interaction } \\
\hline \multicolumn{3}{|c|}{ Fertilizer $x$ year } & $* *$ & $* *$ & $* *$ & NS & NS \\
\hline \multicolumn{3}{|c|}{$\mathrm{LSD}(0.05), \mathrm{N}=164$} & 0.20 & 11.1 & 22.6 & 201 & 40.4 \\
\hline
\end{tabular}

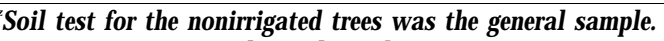

"Mean separation within column by Duncan's NMRT $(P=0.05)$.

${ }^{N s, ; " N}$ Nonsignificant or significant at $\mathrm{P} \leq$ or 0.01 , respectively.

water. More $\mathrm{Ca}$ and $\mathrm{Mg}$ were retained in fertigated soil around the emitter compared with nonirrigated soil.

The data from this study indicate that nitrogen can be applied efficiently through the drip irrigation system without detrimental effects on soil and leaf nutrient concentrations. In fact, lowering the soil $\mathrm{pH}$ and loss of soil nutrients over the general orchard floor (outside the wetted zone) was reduced when $\mathrm{N}$ was fertigated instead of broadcast with no irrigation. Yield and kernel quality were as good under fertigation as when $\mathrm{N}$ was broadcast, and the low- $\mathrm{N}$-all -fertigated treatment was adequate. Irrigation with or without fertigation enhanced yields in several years and increased nut size. Leaf $\mathrm{N}$ concentrations were near or above the adequate range and suggest that the $\mathrm{N}$ application levels can be reduced further. The tests are being continued with the rates of $\mathrm{N}$ halved.

\section{Literature Cited}

Aitken,J. B., 1986. Utilization of irrigation for nutrient application improves efficiency.
Pecan South 20(2):15-18.

Dutcher, I. D., R.E. Worley, I. W. Daniel, R.B. Moss and K.F. Harrison. 1984. Impact of six insecticide-based arthropod pest management strategies on pecan yield, quality, and return bloom under four irrigation/soil fertility regimes. Environ. Entomol. 13:1644-1653.

Edwards, J. H., R.R. Bruce, B.D. Horton, J.L. Chesness, and E.J. Wehunt. 1982. Soil cation and water distribution as affected by $\mathrm{NH}_{4} \mathrm{NO}_{3}$ applied through a drip irrigation system. J. Amer. Soc. Hort. Sci. 107:11421148.

Klein, I., I. Levin, B. Bar-Yosef R. Assaf and A. Berkovitz. 1989. Drip nitrogen fertigation of 'Starking Delicious' apple trees. Plant \& Soil 119:305-314.

Smith, M. W., A.L. Kenwortby, and C.L. Bedford. 1979. The response of fruit trees to injection of nitrogen through a trickle irrigation system. J. Amer. Soc. Hort. Sci. 104:311-313.

Standford, G. and J.O. Legg. 1984. Nitrogen and yield potential, p. 263-272. In: R.D. Hauk (cd.). Nitrogen and crop production. Amer. Soc. Agron., Madison, Wk..

Steel, R. G. D., and J.H. Torrie. 1960. Prin - ciples and procedures of statistics. McGrawHill, New York. p. 194=231.

Trouse, A.C., Jr. 1978. Is traffic affecting pecan production? Pecan South 5(4): 168171.

Wood, B. W., W.R. Joyner, and V. Chew. 1991. Pecan production cycles. HortScience 26:694

Worley, R.E. 1974. Effect of N, P, K, and lime on yield, nut quality, tree growth, and leaf analysis of pecan ( Carya illinoensis W.). J. Amer. Soc. Hort. Sci. 99:49:57.

Worley, R.E. 1985. Use of leaf analysis for basing $\mathrm{N}$ applications for Stuart pecans. Proc. Southeastern Pecan Growers Assn. 78:79-83.

Worley, R.E. 1990. Long-term performance of pecan trees when nitrogen application is based on prescribed threshold concentrations in leaftissue. J. Amer. Soc. Hort. Sci. 115:745-749.

Worley, R. E., S.A. Harmon and R.L. Carter. 1974. Effect of repeated N, P, K and lime applications on soil $\mathrm{pH}, \mathrm{P}$, and $\mathrm{K}$ under old and young pecan trees. J. Amer. Soc. Hort. Sci. 99:57-62. 